Article

\title{
Fiscal Deficits and Stock Prices in India: Empirical Evidence
}

\section{Pooja Joshi * and Arun Kumar Giri}

Economics and Finance Department, New Academic Block, Birla Institute of Technology and Science, Pilani 333031, India; E-Mail: akgiri.bits@gmail.com

* Author to whom correspondence should be addressed; E-Mail: pooja.joshi@pilani.bits-pilani.ac.in; Tel.: +91-969-454-3444.

Academic Editor: George Filis

Received: 24 April 2015/Accepted: 14 August 2015 / Published: 27 August 2015

\begin{abstract}
The study aims at examining how fiscal deficits affect the performance of the stock market in India by using annual data from 1988-2012. The study makes use of Ng-Perron unit root tests to check the non-stationarity property of the series; the Auto Regressive Distributed Lag (ARDL) bounds test and a Vector Error Correction Model (VECM) for testing both short and long run dynamic relationships. The variance decomposition (VDC) is used to predict the exogenous shocks of the variables. The findings of the bounds test reveal that the estimated equation and the series are co-integrated. The ARDL results suggest a long run negative relationship exists between budget deficit and stock prices and do not show any significant relationship in the short run. The VECM result shows that fiscal deficits influence the stock price only in the short run. The results of the Variance Decomposition show that stock price movement in the long run is mostly explained by shocks of fiscal deficits. The study implies that the government must adopt appropriate macroeconomic policies to reduce budget deficit, which will result in stock market growth and in turn will lead to the financial development of the country.
\end{abstract}

Keywords: stock price; fiscal deficit; ARDL; VECM; VDC; India

JEL Classification: H62, H68, G10 


\section{Introduction}

The stock market plays an important role in economic prosperity, fostering capital formation and sustaining the economic growth of an economy [1-4]. The current and the future economic growth of the economy depend on country's stock market performance up to some extent and the stock market performance depends on the country's fiscal budget. This is partly due to the notion that a large budget deficit could affect the current and future economic growth of the nation through its effects on the stock markets. Theoretically, it is true that when the budget of the country is in deficit, it will depress the stock prices and undermine the investor's confidence. Hence, the firm's ability to get capital on favorable terms will be diminished to a large extent. Large budget deficits could lead to a stock market crash [5]. Budget deficits also affect stock prices through anticipated future taxes, particularly if tax rates are below their revenue-maximizing levels [6]. In contrast, however, Friedman [7] claims that budget deficits have little effect on stock prices.

Essentially, large deficits entail additional risks to the economy which include a loss in investor's confidence (domestic and foreign) and adverse effects on the volume of transactions. Specifically, a loss in investor's confidence would cause a shift of portfolio away from home currency assets into foreign currency assets which would limit the ability of the country to finance its liabilities and increase the country's exposure to exchange rate fluctuations. This situation could weaken capital spending and ignite a drop in asset prices which would further restrain real economic activity. Besides fiscal deficit, there are some other macroeconomic variables which are expected to affect stock prices directly or indirectly. Hardouvelis [8] argues that a higher real interest rate adversely affects stock returns because it raises the real discount rate at which cash flows are capitalized, hence increasing the cost of capital, which leads to decrease in real output affecting the profitability and productivity of the industries and hence future cash flows. Sellin [9] lays out competing theories on how money supply affects the stock market prices, namely, those of the Keynesian economists and the real activity theorists. Keynesian economists argue that there is a negative relationship between stock prices and money supply, whereas real activity theorists argue that the relationship between the two variables is positive. The real activity theorist's argument is based on the fact that the increase in the money supply means that money demands are increasing in anticipation of an increase in economic activity. Higher economic activity implies higher expected profitability, which causes stock prices to rise. The inflation rate is one macroeconomic variable that determines the stock price behavior. One way to view the transmission mechanism between these two variables is via the budget deficit. Following the Monetization perspective, a sustained increase in the budget deficit leads to anticipated inflation and an increase in inflation uncertainty. As the budget deficit persists, real rates are pushed up; and the central bank may ease money to reduce these rates, resulting in a rise in inflation and nominal rates. The demand for long-term securities may decrease because financial market participants anticipate a higher rate of inflation or because uncertainty about such an inflationary policy makes long term securities riskier than short-term ones [10].

In India, the average percentage growth rate of inflation was 12.56 in the year 1988-1989 which rose up to 19.30 in the year 1991-1992 and in the 2000-2001 the average percentage annual growth rate of inflation was negative $(-0.33)$. It turned positive in the consecutive year, and in the last few years, the percentage annual growth rate of inflation increased rapidly. Significantly, in 2008-2009 it 
crossed the level of double digits. Money supply in India has increased considerably over the past decades, from Rs. 44.77 billion in 1988-1989 to Rs. 53.92 billion in the year 2000-2001 and to Rs. 76.33 billion in the year 2012-2013, showing an upward trend. Given India's long history of running huge fiscal deficits, the sharp increase in its fiscal deficit over the last few years is a major concern for both academicians and policy makers in India [11,12]. The fiscal deficit of India stood at 7.08\% of GDP in 1988. There was a clear improvement till 1990. After 1991 it started to fall with minor fluctuations till 2007-2008, when it was at its minimum of 2.54\% of GDP in the year 2007-2008. After falling to $2.54 \%$ in 2007-2008, the fiscal deficit to GDP ratio started rising again and was around $5.7 \%$ in 2012 .

The above discussion indicates that there are several factors that affect or are affected by the budget deficit which will then affect stock prices. Therefore, the main objective of this study is to provide some empirical evidence regarding budget deficits and their effects on stock prices and to examine the long run relationship between Fiscal Deficit, Broad Money Supply, Inflation, Real Interest Rate and Stock Market Index by annual time series data from the period of 1988-2012. This study mainly investigates whether changes in deficits cause changes in stock prices and if so, in what direction. For this purpose, the study uses the Autoregressive Distributed Lag (ARDL) method of co-integration. The ARDL approach has several advantages upon other co-integration methods ${ }^{1}$. VECM technique has been used in the study to determine the short run Granger causality between budget deficit and stock prices and the variance decomposition (VDC) is used to predict exogenous shocks of the variables.

This study differs from previous studies in several aspects.

$>$ First of all, only a few attempts are made to study the effects of fiscal deficit on Stock Prices for India.

$>$ Further, in earlier research most of the related studies examine the developed economies, only a few studies are concentrated on emerging markets.

$>$ Besides all these, the research on the topic includes bivariate analysis with conventional econometric techniques. Hence, to know the effect of other macroeconomic variables along with fiscal deficit, on stock prices, the study includes three macroeconomic variables (Inflation, Interest Rates and Money supply) by using the modern ARDL technique.

$>$ The current study also uses a VECM technique to test the short and the long run causal relationship and the VDC to predict exogenous shocks of the variable.

The remainder of this paper is organized as follows. Section 2 discusses the literature review, Section 3 discusses the data and methodology used for the study, Section 4 analyses empirical results and Section 5 presentsa summary and conclusions of the study.

1 The procedure is adopted for three reasons. Firstly, the bounds test is simple as opposed to other multivariate co-integration technique such as [13], it allows co-integrating relationship to be estimated by OLS once the lag order is selected. Secondly, the bound test procedure does not require the pre testing of the variables included in the model for unit root. These approaches require that all the variables to be integrated of the same order (I(1)). Thirdly, the test is relatively more efficient in small sample data sizes as is the case of this study. Fourth the error correction method integrates the short run dynamics with long run equilibrium without losing long run information. 


\section{Literature Review}

The majority of the studies that have been conducted by researchers on the effects of persistent rising fiscal deficits on stock prices have yielded contradictory results. Some researchers, particularly from developed economies, are of the view that large and persistent fiscal deficits can significantly depress stock prices [5,14-18]. Geske and Roll [14] used a simple linear regression model and found that the expected directional impact of budget deficits on stock return should be negative. This is because a government budget deficit exerts upward pressure on the nominal interest rate which, in turn, lowers expected returns on stocks. The increase in risk premia, due to fiscal deficits, exposes investors to an uncertainty surrounding the reaction of the Central Bank and thus further confounds the equity market. Similarly, Laopodis [17], by using vector autoregression (VAR) and Granger causality test, found that large budget deficits adversely impact stock prices. Asaolu and Ogunmuyiwa [19] observed an inverse relationship between budget deficits and the average share prices for the period 1986-2007, by using vector autoregression (VAR) model for co-integration. Quayes [4] studied the association between budget deficit and stock prices by integrating the effects of inflation and the demographic structure by using vector autoregression (VAR) model for co-integration. The model incorporates demand and supply functions to capture the impact of real GDP, inflation, demographic transition, and the budget deficit, on the stock prices. The results from co-integration analysis show that both budget deficits and inflation have a negative impact on stock prices. Osahon and Oriakhi [20], by utilizing vector auto-regression and error-correction mechanisms (ECM) techniques with annual time series data spanning 1984-2010 found that fiscal deficit is negatively related to stock prices. Saleem and Yasir et al. [21], by using the Johansen Cointegration Technique and Granger Causality Test and utilizing annual data from 1990-2010 for Pakistan and India, found that there exists a long run positive causal relationship between budget deficit and stock prices for Pakistan and, on the contrary, in India a long run negative relationship is observed.

In contrast, Van Aarle et al. [22] used a structural vector auto-regression (SVAR) approach and provide evidence supporting the positive relationship between fiscal policy and stock prices using structural VAR analysis. Udegbunam and Oaikhenan [23] found that money-financed deficits have an ambiguously positive effect on stock prices in the short run. Ardagna [24] reports that adjustments based on expenditure reduction are related to increases in stock market prices. Darrat [25] in his examination of the effect of monetary and fiscal policies on shares in Canada by using multivariate Granger-causality modeling technique concludes that budget deficits determine share returns, but did not ascertain whether it is positive, negative or ambiguous.

Fama and Schwert [26], Schwert [27], Fama [28], Quayes and Jamal [29], Gallagher and Taylor [30,31], Rapach [32], and Feldstein [33] have shown that inflation can have a negative impact on stock prices in industrialized countries, but Al-Khazali and Pyun [34] and Spyrou [35] showed that such a negative relationship may not hold true for emerging economies. However, some studies from Pearce and Roley [36] and Hardouvelis [37] found no significant relationship between the two variables. Since the relationship between inflation and stock prices is not clear, it is important for researchers to find out the behavior of the variables.

Maysami and Koh [38] found a positive relationship between money supply changes and stock returns in Singapore. Bailey [39] also stated that innovation to the monetary variable had a large positive 
impact on the index. Similar results were found by Maskay [40], Bernanke and Kuttner [41] and Alatiqi and Fazel [42] who asserted that a change in the money supply positively affects stock prices. On the contrary, Osahon and Oriakhi [20] found that money supply is negatively related to stock prices. Gan, Lee, Yong, and Zhang [43] found a negative impact of a shock to the money supply on the stock index. This was explained by the fact that the money supply in New Zealand is influenced mainly by foreign investors. They argue that if the interest rate is high relative to other countries, the investors are likely to leave their money in the bank rather than to invest in the risky stock market. If the interest rate is too low, then the investors may want to invest in other markets.

Hsing [44] using the VAR model and Arango [45] found an inverse relationship between the share prices on the Bogota stock market and the interest rate which was measured by the inter bank loan interest rate. Uddin and Alam [46] found that Interest Rate has a significant negative relationship with Share Price and Changes of Interest Rate has a significant negative relationship with Changes of Share Price. Similar results were found by Alam and Uddin [47]. Osahon and Oriakhi [20] found that interest rates are negatively related to stock prices. Besides all these studies Rizalito [48] found no significant relationship between 91-day interest rates and the composite sectoral indices of the Makati Stock Exchange using data from January 1987 to August 1993.

\section{Methodology and Data Description}

\subsection{Model Specification and Data}

The following general specification has been used in this study to empirically examine the effect of fiscal deficit and other fundamental macroeconomic factors on the stock market:

$$
\operatorname{LBSE}_{t}=\alpha_{0}+\alpha_{1} L F D_{t}+\alpha_{2} L M 3_{t}+\alpha_{3} L C P I_{t}+\alpha_{4} L R I N T_{t}+\varepsilon_{t}
$$

where LBSE $=$ Sensitivity index of Bombay Stock Exchange $($ Sensex $)$, LFD $=$ Fiscal Deficit as a percentage of GDP, LM3 = Money Supply (broad money), LCPI = Consumer Price Index; And LRINT = Real Interest rate variable in the general model specification above. All variables are taken in $\log$ form.

Stock market development is usually measured by stock market size, liquidity, volatility, concentration and integration with world capital markets. The stock market index is Sensex (or BSE 30), an index of 30 well established and financially sound companies listed on the BSE. The Sensex is intended to represent an entire stock market and thus track the market changes over time. Therefore, in this study, we have taken the sensitivity index of BSE (Sensex) to track the changes in the market over time (with respect to other macroeconomic variables) represented by LBSE (Naik and Padhi [49], Saleem and Yasir et al. [21], Singh [50]; and Tripathi and Seth [51] used different methodologies with different data periods).

FD is the Fiscal Deficit as a percentage of GDP [21] and FD has a significant negative relationship with the stock prices $([4,14,17,19,21])$; the negative relationship is because of several reasons: first, large government debts often coincide with high interest rates, which can push governments toward policies that create inflation. That hit investor confidence and can possibly lead to a bear market; second, the fiscal measures undertaken by the government affect public expenditure. For instance, an increase in direct taxes would decrease disposable income, thus reducing demand for goods. This 
decrease in demand will translate into a decrease in production, therefore affecting economic growth; third, an increase in indirect taxes would also decrease demand. This is because indirect taxes are often partially or completely passed on to consumers in the form of higher prices. Higher prices imply a reduction in demand and this in turn would reduce profit margins of companies, thus slowing down production and growth (Money Control). Whereas some researchers found a positive association between Fiscal Deficit and Stock prices [21-23], few others found an ambiguous relationship between Fiscal Deficit and stock prices [24,25].

In this study, money supply has been measured through M3 (Broad money) and has increasingly been recognized as a major source of financial development. Some researchers argue that there exists a negative relationship between stock prices and money supply $[20,36]$, whereas some other theorists argue that the relationship between the two variables is positive [52]. The latter argument is based on the fact that the increase in the money supply means that money demands is increasing in anticipation of an increase in economic activity. Higher economic activity implies higher expected profitability, which causes stock prices to rise.

Inflation represents one of the major threats to stock investors. When the inflation rates start to rise, investors get very nervous anticipating the potentially negative consequences and therefore because of lack of confidence among investors, they resist to invest in the stock market which leads to a decline in stock prices. Therefore, researcher Fama [28] found a negative relationship between inflation and stock prices. On the other hand, a positive relationship is also possible between inflation and stock prices as unexpected inflation raises the firms' equity value if they are net debtors [53,54].

The interest rate is one macroeconomic variable that determines the stock price behavior. Some researchers found a negative relationship between interest rate and stock prices [44,46,47] and this generally assumed negative relationship is partly based on the view that a decrease in interest rates leads to lower borrowing costs for firms, higher future profits, and thus higher stock prices. It is also argued that lower interest rates prompt investors to move money from the bond market to the equity market.

The study empirically estimated the effect of Fiscal Deficit and other fundamental macroeconomic variables with the help of the above described methodology for India. The study uses annual data on the above described variables covering the period from 1988 to 2012. The data has been taken and compiled from Handbook of Statistics on Indian economy, RBI; Economic Survey, Govt. of India; World Bank database; Official website of SEBI and RBI.

\subsection{Co-Integration with ARDL}

To empirically analyze the long run relationship and dynamic interaction of Stock Market Index with macroeconomic variables, the above model has been estimated by the auto regressive lag (ARDL) co-integration procedure developed by Pesaran et al. [55]. The procedure is adopted for three reasons. Firstly, the bounds test is simple as opposed to other multivariate co-integration technique such as [13]; it allows a co-integrating relationship to be estimated by OLS once the lag order is selected. Secondly, the bounds test procedure does not require the pre-testing of the variables included in the model for unit root unlike other techniques such as [56,57]. These approaches require that all the variables to be integrated of the same order (I(1)). Otherwise the predictive power will be lost [58-60]. However, ARDL technique is applicable irrespective of whether regressor in the model is $\mathrm{I}(0)$ or $\mathrm{I}(1)$. The 
procedure will, however crash in the presence of I(2) series. Thirdly, the test is relatively more efficient in small sample data sizes as is the case of this study. Fourth the error correction method integrates the short run dynamics with long run equilibrium without losing long run information. The unrestricted error correction model (UECM) of ARDL model used to examine the long run and the short run relationship takes the following form:

$$
\begin{gathered}
\Delta L B S E_{t}=\delta_{0}+\delta_{1} T+\delta_{2} L F D_{t-1}+\delta_{3} L M 3_{t-1}+\delta_{4} L C P I_{t-1}+\delta_{5} L R I N T_{t-1}+\sum_{i=1}^{q} \alpha_{i} \Delta L B S E_{t-i}+ \\
s \sum_{i=1}^{q} \beta_{i} \Delta L F D_{t-i}+\sum_{i=1}^{q} \mu_{i} \Delta L M 3_{t-i}+\sum_{i=1}^{q} \sigma_{i} \Delta L C P I_{t-i}+\sum_{i=1}^{q} \omega_{i} \Delta L R I N T_{t-i}+\varepsilon_{t}
\end{gathered}
$$

where the series is as defined earlier and $\mathrm{T}$ is time trend and $\mathrm{L}$ implies that the variables have been transformed in natural logs. The first part of the Equation (2) with $\delta 2, \delta 3, \delta 4$ and $\delta 5$ refer to the long run coefficients and the second part with $\alpha, \beta, \mu, \sigma, \omega$ refers to the short run coefficients. The null hypothesis of no co-integration $\mathrm{H} 0: \delta 1=\delta 2=\delta 3=\delta 4=\delta 5=0$ and the alternative hypothesis H1: $\delta 1 \neq \delta 2 \neq \delta 3 \neq \delta 4 \neq \delta 5 \neq 0$ implies co-integration among the series (Equation (2)).

The first step in the ARDL test is to estimate the Equation (2) by OLS in order to test for the existence of a long run relationship among variables by conducting an F-test for the joint significance of the coefficients of the lagged levels of variables i.e., $\mathrm{H}_{0}$ (Null hypothesis) as against $\mathrm{H}_{1}$ (Alternative hypothesis) as stated earlier.

In the second step, once the co-integration is established, the conditional ARDL long run model for $\mathrm{LBSE}_{t}$ is used. In the third and final step, we obtain the short run dynamic parameters by estimating an error correction model with the long run estimates. This is specified as below:

$$
\begin{gathered}
\Delta L B S E_{t}=\mu+\sum_{i=1}^{q} \alpha_{i} \Delta L B S E_{t-i}+\sum_{i=1}^{q_{1}} \beta_{i} \Delta L F D_{t-i}+\sum_{i=1}^{q_{2}} \mu_{i} \Delta L M 3_{t-i}+\sum_{i=1}^{q_{3}} \sigma_{i} \Delta L C P I_{t-i} \\
+\sum_{i=1}^{q_{4}} \omega_{i} \Delta \operatorname{LRINT}_{t-i}+\phi E C M_{t-1}+\varepsilon_{t}
\end{gathered}
$$

where $\alpha, \beta, \mu, \sigma, \omega$ are short run dynamic coefficient to equilibrium and $\phi$ is the speed adjustment coefficient.

\subsection{Granger Causality Test}

The cointegration relationship indicates the existence of a causal relationship between variables, but it does not indicate the direction of causal relationships between variables. Therefore, it is common to test for detecting the causal relationship between variables using the Engle and Granger (1987) [56] test procedure. There are three different models that can be used to detect the direction of causality ${ }^{2}$ between two variables $\mathrm{X}$ and $\mathrm{Y}$ depending on the order of integration and the presence or absence of a cointegration relationship. If two variables say $\mathrm{X}$ and $\mathrm{Y}$ are individually integrated of order one $\mathrm{I}(1)$ and co-integrated, then the Granger causality test may use I(1) data because of super consistency

2 Causality is the relation between an event (the cause) and a second event (the effect)s, where the first event is understood to be responsible for the second. In common usage, causality is also the relation between causes and the effect. Whereas, the Granger causality test is a statistical hypothesis test for determining whether one time series is useful in forecasting another, first proposed by Granger [61]. Granger [61] argued that causality in economics could be tested for by measuring the ability to predict the future values of a time series using prior values of another time series. 
properties of estimators. If $\mathrm{X}$ and $\mathrm{Y}$ are $\mathrm{I}(1)$ and co-integrated, the Granger causality test can be applied to I(0) data with an error correction term. If X and $Y$ are I(1) but not co-integrated, the Granger causality test requires transformation of the data to make $\mathrm{I}(0)$. In this paper, the presence of cointegration relationship the application of Engle and Granger (1987) [56] causality test in the first differenced variables by means of a VAR will mislead the results; therefore an inclusion of an additional variable to the VAR system such as the error correction term would help us to capture the long run relationship. The augmented form of the Granger causality test involving the error correction term is formulated in a multivariate $p$ th order vector error correction model given as below:

$$
\left(\begin{array}{c}
\Delta L B S E_{t} \\
\Delta L F D_{t} \\
\Delta L C P I_{t} \\
\Delta L M 3_{t} \\
\Delta L R I N T_{t}
\end{array}\right)=\left(\begin{array}{l}
C 1 \\
C 2 \\
C 3 \\
C 4 \\
C 5
\end{array}\right)+\sum_{i=1}^{p}\left[\begin{array}{lllll}
\beta_{11 i} & \beta_{12 i} & \beta_{13 i} & \beta_{14 i} & \beta_{15 i} \\
\beta_{21 i} & \beta_{22 i} & \beta_{23 i} & \beta_{24 i} & \beta_{25 i} \\
\beta_{31 i} & \beta_{32 i} & \beta_{33 i} & \beta_{34 i} & \beta_{35 i} \\
\beta_{41 i} & \beta_{42 i} & \beta_{43 i} & \beta_{44 i} & \beta_{45 i} \\
\beta_{51 i} & \beta_{52 i} & \beta_{53 i} & \beta_{54 i} & \beta_{55 i}
\end{array}\right]\left(\begin{array}{c}
\Delta L B S E_{t-i} \\
\Delta L F D_{t-i} \\
\Delta L C P I_{t-i} \\
\Delta L M 3_{t-i} \\
\Delta L R I N T_{t-i}
\end{array}\right)+\left(\begin{array}{c}
\gamma_{1} \\
\gamma_{2} \\
\gamma_{3} \\
\gamma_{4} \\
\gamma_{5}
\end{array}\right) E C M_{t-1}+\left(\begin{array}{c}
\varepsilon_{2 t} \\
\varepsilon_{3 t} \\
\varepsilon_{4 t} \\
\varepsilon_{5 t}
\end{array}\right)
$$

The C's, $\beta$ 's and $\gamma$ 's are the parameters to be estimated. $\mathrm{ECM}_{t-1}$ represents the one period lagged error-term derived from the cointegration vector and the $\varepsilon$ 's is serially independent with mean zero and finite covariance matrix. From Equation (4) given the use of a VAR structure, all variables are treated as endogenous variables. The $\mathrm{F}$ test is applied here to examine the direction of any causal relationship between the variables. The FD variable does not Granger cause BSE in the short run, if and only if all the coefficients of $\beta 12 i$ 's are not significantly different from zero in Equation (4). These are referred to as the short run Granger causality test. The coefficients on the ECM represent how fast deviations from the long run equilibrium are eliminated. Another channel of causality can be studied by testing the significance of ECM's. This test is referred as the long run causality test.

\section{Empirical Results}

\subsection{Unit Root Test}

Before we proceed to ARDL testing, we test for unit root of the variables to determine their order of integration. The test for unit root is to ensure that none of the series is integrated at $I(2)$. In the present study, we have used Ng-Perron unit root tests. The results of the newly developed Ng-Perron test developed by Ng-Perron [62] are presented in Table 1. The analysis of the unit root test results indicates that the variables are integrated order one $(\mathrm{I}(1))$ and none of the variables are $\mathrm{I}(2)$ series $^{3}$.

Table 1. Unit root test: Ng-Perron Test.

\begin{tabular}{|c|c|c|c|c|c|}
\hline \multirow{2}{*}{ Variables } & \multicolumn{4}{|c|}{ With Trend and Intercept } & \multirow{2}{*}{$\begin{array}{c}\text { Stationarity } \\
\text { Status } \\
\end{array}$} \\
\hline & Mza & Mzt & MSB & MPT & \\
\hline LBSE & -0.504 & -0.239 & 0.473 & 16.189 & $\mathrm{I}(1)$ \\
\hline$\Delta$ LBSE & -11.187 & -2.363 & 0.211 & 2.195 & \\
\hline LFD & -1.851 & -1.981 & 0.252 & 3.120 & $\mathrm{I}(1)$ \\
\hline$\Delta \mathbf{L F D}$ & -10.896 & -2.322 & 0.213 & 2.294 & \\
\hline LM3 & -0.267 & -0.149 & 0.559 & 20.937 & $\mathrm{I}(1)$ \\
\hline
\end{tabular}

3 ARDL technique is applicable irrespective of whether regressor in the model is $\mathrm{I}(0)$ or $\mathrm{I}(1)$. 
Table 1.Cont.

\begin{tabular}{|c|c|c|c|c|c|}
\hline \multirow{2}{*}{ Variables } & \multicolumn{4}{|c|}{ With Trend and Intercept } & \multirow{2}{*}{$\begin{array}{c}\text { Stationarity } \\
\text { Status } \\
\end{array}$} \\
\hline & Mza & Mzt & MSB & MPT & \\
\hline$\Delta L M 3$ & -10.130 & -2.218 & 0.219 & 2.539 & \\
\hline LCPI & -2.918 & -0.385 & 0.135 & 1.441 & $\mathrm{I}(1)$ \\
\hline$\Delta \mathrm{LCPI}$ & -17.659 & -1.920 & 0.250 & 3.329 & \\
\hline LRINT & -2.488 & -0.074 & 0.218 & 2.967 & $\mathrm{I}(1)$ \\
\hline$\Delta$ LRINT & -8.930 & -2.102 & 0.235 & 2.781 & \\
\hline
\end{tabular}

Source: Author's own Calculation by using E-views 8.0. $\Delta$ denotes the first difference of the series. $\mathrm{L}$ implies that the variables have been transformed in natural logs.

\subsection{Lag Length Selection before Co-Integration}

The next step involves estimating the model and determining the rank, $r$ to find the number of co-integrating relations in our model. In the ARDL model specification, it has been specified that the number of lags is the same for all the variables taken for the study because all these variables are incorporated in a model as specified in Equation (1), where LBSE is taken as dependent variable and other variables as independent. The optimal lag length was determined by different criterion suitable to the models (Table 2) using two maximum lags in the model. The aim is to choose the number of parameters, which minimizes the value of the information criteria.

Table 2. Lag Order Selection Criterion.

\begin{tabular}{ccccccc}
\hline Lag & $\boldsymbol{L o g} \boldsymbol{L}$ & $\boldsymbol{L R}$ & $\boldsymbol{F P E}$ & $\boldsymbol{A I C}$ & $\boldsymbol{S I C}$ & $\boldsymbol{H Q}$ \\
\hline 0 & -8.382 & NA & $2.20 \times 10^{-6}$ & 1.163 & 1.410 & 1.225 \\
$1 *$ & 116.236 & $184.218^{*}$ & $4.05 \times 10^{-10 *}$ & $-7.498 *$ & $-6.017 *$ & $-7.126 *$ \\
2 & 139.492 & 24.266 & $6.78 \times 10^{-10}$ & -7.347 & -4.631 & -6.664 \\
\hline
\end{tabular}

* Indicates lag order selected by the criterion; LR: sequential modified LR test statistic (each test at the 5\% level); FPE: Final prediction error; AIC: Akaike information criterion; SIC: Schwarz information criterion; HQ: Hannan-Quinn information criterion.

\subsection{ARDL Bounds Test}

The paper estimates the ARDL bounds test approach to co-integration. We used AIC, LR, SIC, HQ and FPE for selecting a minimum lag order of 1 for conditional ARDL-VECM, by applying the procedure in OLS regression for the first difference part of the Equation (2) and then testing for the joint significance of the parameters of the lagged level variables when added to the first regression. The F-Statistics test the joint Null hypothesis that the coefficients of lagged level variables are zero. Table 3 reports the result of the calculated F-Statistics which are more than UCB which is at 5\% (Pesaran [55] or Narayan [63]). Thus the Null Hypothesis of no co-integration is rejected, implying long run co-integrating relationship amongst the stock market index and economic growth. The estimated statistics show that the model specification seems to pass all diagnostic tests successfully. 
Table 3. ARDL bounds test results.

\begin{tabular}{ll}
\hline Panel I: Bounds Testing to Co-Integration: \\
\hline Estimated Equation: $L B S E=F(L F D ~ L M 3$ & $L C P I L R I N T)$ \\
\hline Indicators & 01 \\
\hline Optimal lag & 4.715 \\
\hline F-Statistics & \\
\hline Panel II: Diagnostic Tests & 0.8801 \\
\hline Diagnostic Tests Indicators & 1.5414 \\
\hline Normality J-B value & 1.0245 \\
Serial Correlation LM Test & 0.0714 \\
\hline Heteroscedasticity Test (ARCH)
\end{tabular}

Once we established that a long run co-integrating relationship exists, Equation (4) was estimated using $\operatorname{ARDL}(1,0,0,0)$ specification. The results of long run estimation have been shown in Table 4, which shows that the coefficient of FD is negative and significant at the $1 \%$ level. It means that FD has a significant negative relationship with the stock market index. This implies that FD is negatively affecting stock market index, which shows that with the increase in Fiscal deficit, stock market index is decreasing. This is due to the fact that the extent of fiscal deficit and means of financing it, influence the money supply and the interest rate in the economy. High interest rates mean higher cost of capital for the industry, lower profits and hence lower stock prices. The findings are consistent with $[4,14,17,19,21]$; but contrast to the findings of Van Aarle et al. [22] and Udegbunam and Oaikhenan [23].

The coefficient of money supply has a positive impact on the Stock Market and it is significant at the $1 \%$ level. The value of coefficient implies that a $1 \%$ increase in M3 leads to an increase in stock market index with the fact that the increase in the money supply meaning that money demands are increasing in anticipation of an increase in economic activity. Higher economic activity implies higher expected profitability, which causes stock prices to rise ${ }^{4}$. Considering the impact of inflation, it is significant at $1 \%$ and has a positive impact on a market index. This finding supports the views of Kessel [53] and Ioannidis et al. [54]. The coefficient of real interest rate is positive, but not significant which shows there is no significant relationship between LRINT and stock market index.

The results of short run dynamics using the ECM version of ARDL are reported in Table 5. The short run adjustment process is examined from the ECM coefficient. The coefficient of the error correction term is an adjustment coefficient capturing the proportion of the disequilibrium in economic growth in one period which is corrected in the next period. The coefficient generally represents the speed of adjustment towards equilibrium, that means how quickly the equilibrium is established if the path is in disequilibrium. The larger the error term, the earlier the economy's return to the equilibrium rate of growth; following a shock. The coefficient lies between 0 and -1 , the equilibrium is converging to the long run equilibrium path and is responsive to any external shocks.

4 Homa and Jaffe [52]. 
Table 4. Estimated Long Run Coefficients using ARDL Approach (Dependent variable: LBSE).

\begin{tabular}{|c|c|c|c|}
\hline \multirow{2}{*}{ Regressors } & \multicolumn{3}{|c|}{$\operatorname{ARDL}(1,0,0,0)$} \\
\hline & Coefficient & t-Values & Prob. Values \\
\hline LFD & $-1.597 *$ & -4.201 & {$[0.001]$} \\
\hline LM3 & $2.840 *$ & 7.226 & {$[0.000]$} \\
\hline LCPI & $0.931 *$ & 4.751 & {$[0.000]$} \\
\hline LRINT & 0.005 & 0.040 & [0.968] \\
\hline CONS & -1.930 & -0.875 & {$[0.394]$} \\
\hline \multicolumn{4}{|l|}{ Robustness Indicators } \\
\hline $\mathrm{R}^{2}$ & \multicolumn{3}{|c|}{0.980} \\
\hline Adjusted $\mathrm{R}^{2}$ & \multicolumn{3}{|c|}{0.971} \\
\hline F Statistics & \multicolumn{3}{|c|}{112.92} \\
\hline Durbin Watson Stat & \multicolumn{3}{|c|}{2.2876} \\
\hline Serial Correlation, F & \multicolumn{3}{|c|}{$1.162[0.281]$} \\
\hline Heteroskedasticity, F & \multicolumn{3}{|c|}{$2.471[0.116]$} \\
\hline Ramsey reset test, $\mathrm{F}$ & \multicolumn{3}{|c|}{$0.197[0.657]$} \\
\hline
\end{tabular}

Note: (1) The lag order of the model is based on Schwarz Bayesian Criterion (SBC); (2) * indicates significant at the 1 percent level of significance.

Table 5. Estimated Short Run Coefficients using ARDL Approach (Dependent variable: LBSE).

\begin{tabular}{cccc}
\hline \multirow{2}{*}{ Regressors } & \multicolumn{3}{c}{ ARDL(1,0,0,0) } \\
\cline { 2 - 4 } & Coefficient & t-Ratio & Prob. Values \\
\hline$\Delta$ LFD & -0.211 & -1.330 & {$[0.200]$} \\
$\Delta$ LM3 & $1.453 *$ & 3.795 & {$[0.001]$} \\
$\Delta$ LCPI & $0.274 * * *$ & 2.811 & {$[0.012]$} \\
$\Delta$ LRINT & 0.002 & 0.040 & {$[0.968]$} \\
$\Delta$ CONS $^{*}$ & -0.987 & -0.815 & {$[0.425]$} \\
ECM $_{t-1}$ & -0.511 & -5.547 & {$[0.000]$} \\
\hline Robustness Indicators & \multicolumn{3}{l}{} \\
\hline R $^{2}$ & 0.716 & & \\
Adjusted R2 & 0.592 & & \\
Durbin Watson Stat & 2.288 & & \\
SE Regression & 0.151 & & \\
RSS & 0.366 & & \\
F Statistics & $8.072[0.000]$ & \\
\hline
\end{tabular}

Note: (1) The lag order of the model is based on Schwarz Bayesian Criterion (SBC); (2)* and *** indicate significant at the $1 \%$ and $10 \%$ level of significance, respectively.

The comparison of long run coefficients with that of short run ECM coefficients confirms that the directions of relationships are maintained. However, the Fiscal Deficit was negative and significant at the $1 \%$ level in the long run and failed to explain the variation in the stock market index significantly in the short run. This may be due to the fact that investor's behavior in the stock market is regulated by long term fiscal deficit and may not bother about short term fluctuations in it. Other variables, such as M3 (1\%) and CPI (10\%) are significant and positively influencing the market index both in the short run as well as in the long run. Here also, the coefficient of RINT is positive, but not significant in both long run as well as short run. Table 5 also shows that the coefficient of $\operatorname{ECM}_{(t-1)}$ is significant at the 
$1 \%$ level, which indicates that the speed of adjustment for a short run to reach long run is significant. Further, the error correction term is -0.51 with expected sign, suggesting that when the stock price is above or below its equilibrium level, it adjusts by almost $51 \%$ per year and the full convergence process takes about two years.

The short run and long run Granger causality test findings are reported in Table 6. In the above table the values mentioned under the heading $\operatorname{ECM}_{(t-1)}$ are indicating long run Granger causality, whereas, the rest of the values are the values of F-test. The results of Table 6 indicate short run unidirectional causality running from LFD to LBSE in India. It is also observed that error correction term is statistically significant for specification with LBSE as the dependent variable which indicates that there exists a long run causal relationship among the variable with LBSE as the dependent variable. The result is also confirmed by the ARDL test statistics.

Table 6. Results of Vector Error Correction Model.

\begin{tabular}{ccccccc}
\hline & \multicolumn{6}{c}{ Sources of Causation } \\
\cline { 2 - 7 } Dependent Variable & \multicolumn{5}{c}{ Short Run Independent Variables } & $\begin{array}{c}\text { Long Run } \\
\text { Independent Variables }\end{array}$ \\
\cline { 2 - 7 } & $\Delta$ LBSE & $\Delta$ LFD & $\Delta$ LCPI & $\Delta$ LM3 & $\Delta$ LRINT & ECM $_{(t-1)}$ \\
\hline$\Delta$ LBSE & - & $4.464 *$ & 0.458 & 0.361 & 0.000 & $-4.874 *$ \\
$\Delta$ LFD & 0.145 & - & 0.132 & 0.667 & 1.403 & -1.061 \\
$\Delta$ LCPI & 0.063 & 0.062 & - & 0.115 & 0.017 & -0.042 \\
$\Delta$ LM3 & 0.098 & 0.653 & 0.511 & - & 0.053 & -0.505 \\
$\Delta$ LRINT & $10.031 *$ & $9.702 *$ & 0.183 & $8.907 *$ & - & -0.337 \\
\hline \multicolumn{7}{c}{$*$ Indicates $1 \%$ level of significance. }
\end{tabular}

The robustness of the short run results are investigated with the help of diagnostic and stability tests. The ARDL-VECM model passes the diagnostic against serial correlation, functional misspecification and non-normal error. The cumulative sum (CUSUM) and the cumulative sum of square (CUSUMSQ) tests have been employed in the present study to investigate the stability of a long run and short run parameters. The cumulative sum (CUSUM) (Figure 1) and the cumulative sum of square (CUSUMSQ) plots is between critical boundaries at $5 \%$ level of significance. This confirms the stability property of a long run and short run parameters which have an impact on the market index in case of India. This confirms that the models seem to be steady and are specified as appropriate.
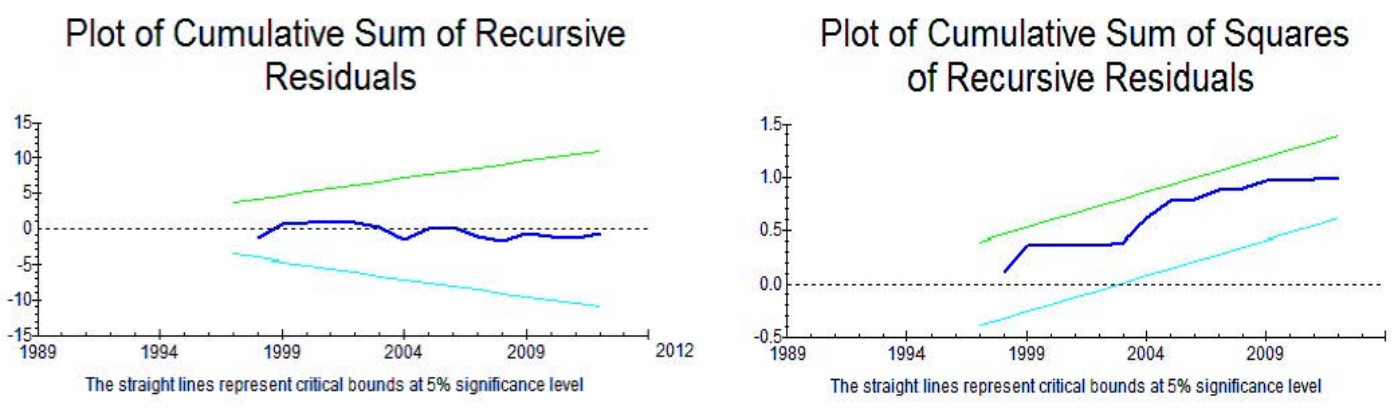

Figure 1. Stability Test. 


\subsection{Variance Decomposition (VDC) Analysis}

Brooks [64] stated that variance decomposition accounts for the share of variations in the endogenous variables resulting from the endogenous variables and the transmission to all other variables in the system, because of the dynamic nature of the VAR. Hence, VDC gives the proportion of the movements in the dependent variables that are due to their "own" shocks, versus shocks to the other variables. It is pointed out by Pesaran and Shin [55] that the variable decomposition method shows the contribution in one variable due to innovation shocks stemming in the forcing variables. The variance decomposition indicates the amount of information each variable contributes to the other variables in the auto regression. It determines how much of the forecast error variance of each of the variables can be explained by exogenous shocks to the other variables. The main advantage of this approach is it is insensitive to the ordering of the variables. The residuals generated by the VAR models are usually contemporaneously correlated. This is because in a VAR model only lagged endogenous variables are admitted on the right-hand side of each equation (in addition to a constant term), and hence all the contemporaneous shocks which impact on LBSE are forced to feed through the residuals [65]. While this may not cause a problem in the estimation of the VAR model, the impulse responses and variance decompositions derived from the initial estimates of the VAR model could be affected such that any adjustment to the order in which the variables are entered in the system could produce different results [65]. Thus, there is a need to impose some restrictions when estimating the VAR model to identify the VDC. In this regard, a common approach is the Cholesky decomposition, which was originally applied by Sims [66]. The Cholesky decomposition overcomes the problem of contemporaneous relationships among the innovations error terms within the estimated VAR model by identifying the structural shocks such that the covariance matrix of the estimated residuals is lower triangular.

The ordering of the variables was done after going through the iteration process and we have tried various ordering of variables to check the consistency of the results. The main principal of Cholesky ordering is that the first variable should be selected such that it is the only one with potential immediate impact on other variables. The ordering of the variables was based on the assumption that a shock in the real interest rate would be contemporaneously transmitted to money supply, fiscal deficit, inflation and stock prices, and a shock in money supply would be transmitted to the fiscal deficit, which would, in turn, affect inflation. However, this shock in money supply will not affect the interest rate variable. Similarly, the shock in fiscal deficit would contemporaneously affect inflation and stock prices, but not to the money supply and interest rate.

The results of the VDC are presented in Table 7. The column SE is the forecast error of the variable to be forecast at different lengths into the future. The empirical evidence indicates that $57.86 \%$ of stock prices change is contributed by its own innovative shocks. Further shock in fiscal deficit explains stock prices by $21.03 \%$ and the money supply contributes to market capitalization by $16.08 \%$. The share of other variables is very minimal. Thus, the result indicates that the stock prices behave exogenously. During the initial period, the variation in changes in stock prices is caused by the stock price itself. As time passes, the change in LBSE is contributed by fiscal deficit. However, the impact exerted by other macroeconomic variables on stock prices is very low. Therefore, it can be said that over the 
horizon of 10 years, fiscal deficit plays the most important role, explaining $21 \%$ variation in stock market prices in India.

Table 7. Variance Decomposition (VDC) Analysis.

\begin{tabular}{ccccccc}
\hline Period & S.E. & LBSE & LCPI & LFD & LM3 & LRINT \\
\hline 1 & 0.193 & 100.000 & 0.000 & 0.000 & 0.000 & 0.000 \\
2 & 0.283 & 84.980 & 0.009 & 12.600 & 0.048 & 2.361 \\
3 & 0.333 & 76.863 & 0.313 & 19.045 & 1.508 & 2.269 \\
4 & 0.362 & 70.667 & 1.028 & 21.937 & 4.441 & 1.925 \\
5 & 0.380 & 65.830 & 1.737 & 22.716 & 7.835 & 1.880 \\
6 & 0.391 & 62.444 & 2.180 & 22.449 & 10.843 & 2.081 \\
7 & 0.398 & 60.313 & 2.346 & 21.888 & 13.100 & 2.350 \\
8 & 0.403 & 59.051 & 2.352 & 21.427 & 14.606 & 2.562 \\
9 & 0.406 & 58.306 & 2.320 & 21.165 & 15.531 & 2.676 \\
10 & 0.408 & 57.861 & 2.321 & 21.037 & 16.068 & 2.711 \\
\hline \multicolumn{6}{c}{ Cholesky Ordering: LBSE LCPI LFD LM3 LRINT } \\
\hline
\end{tabular}

Note: All the values of VDC are calculated using E-views 8.0.

\section{Conclusions and Policy Implications}

An effort has been made in this paper to investigate whether fiscal deficit and other macroeconomic variables affect the stock price in India or not. Towards this effort, we have used annual data from 1988-2012 for all the variables included in the estimation. The present paper used ARDL bounds testing co-integration and error correction model (ECM) for short run dynamics. The study makes use of Ng-Perron unit root tests to check the non-stationarity property of the series. The test statistics of the unit root suggest that none of the variables included in the study are I(2). The bounds test confirms that the estimated equation and the series are co-integrated. The ARDL results suggest a long run negative and significant relationship exists between budget deficit and stock prices. However, the relationship does not show any significant results in the short run. The findings imply that, in a country when the budget is in deficit, it will depress the stock prices and undermine the investor's confidence, so the firm's ability to get capital on favorable terms will be diminished in the long run.

Further, as the deficit increases, future tax burden, interest rates, and the dollar value increases, leading to decrease in corporate profits because of weak domestic as well as export revenues. So, sales decrease which ultimately lowers net earnings, thus decreasing equity prices. These findings are analogous with the work of Adrangi and Allender [67]; Salem and Yasir et al. [21]. However, investors are indifferent to the short run fluctuations in the fiscal deficits. The money supply and inflation in India influence stock prices positively both in the long run as well as in the short run. The findings suggest that the increase in money supply leads to increase in money demand in anticipation of an increase in economic activity. Higher economic activity implies higher expected profitability, which causes stock prices to rise. The error correction term is negative and significant and full convergence process between stock prices and macroeconomic variables takes about two years in India.

To determine the direction of causality, VECM is used in the study and the result shows that there exists a short runGranger causality running from fiscal deficit to stock price. Further, the result 
indicates the presence of long run Granger causality for the equation with the stock price as the dependent variable. The CUSUM and CUSUMSQ test results suggest the policy changes considering the explanatory variables of the stock price equation will not cause major distortions in India. To predict the long run and short run shocks variance decomposition technique has been used and the results of the VDC analysis show that the fiscal deficit plays an important role in explaining the variation in stock prices in India.

The implications of the present study are multifaceted. The result suggests a negative impact of fiscal deficit on the stock prices in India. Hence, the government must adopt appropriate policies to improve budget deficit. A stable government with stable policies can help in achieving confidence among foreign and domestic investors. If the government seriously targets these variables, the stock market will develop resulting in the financial development of the country.

\section{Author Contributions}

Both authors have equally contributed to the paper.

\section{Conflicts of Interest}

The authors declare no conflict of interest.

\section{References}

1. Adjasi, C.K.D.; Harvey, S.K.; Agyapong, D. Effect of exchange rate volatility on the Ghana stock exchange. Afr. J. Account. Econ. Financ. Bank. Res. 2008, 3, 28-47.

2. Hamrita, M.; Abdallah, N.; Ammou, S. The Multi-Scale Interaction between Interest Rate, Exchange Rate and Stock Price; MPRA Paper No. 18424; 2009. Available online: http://mpra.ub.uni-muenchen.de/id/eprint/18424 (accessed on 22 August 2015).

3. Pilinkus, D. Stock Market and Macroeconomic Variables: Evidence from Lithuania. Econ. Manag. 2009, 14, 884-891.

4. Quayes, S. Does budget deficit lower equity prices in USA. Econ. Lett. 2010, 107, 155-157.

5. Roley, V.V.; Schall, L.D. Federal deficits and the stock market. Econ. Rev. Federal Reserve Bank Kansas City 1988, 73, 17-27.

6. Hall, R.E.; Taylor, J.B. Macroeconomics: Theory, Performance and Policy, 4th ed.; W.W. Norton, New York, NY, USA, 1993.

7. Friedman, M. An Economist's Growing Garden of Fallacies. Hum. Events 1988, 48, 16.

8. Hardouvelis, G.A. Macroeconomic Information and Stock Prices. J. Econ. Bus. 1988, 39, 131-140.

9. Sellin, P. Monetary Policy and the Stock Market: Theory and Empirical Evidence. J. Econ. Surv. 2001, 15, 491-541.

10. Feldstein, M. The Budget Deficit and the Dollar; Working paper No. 1898, National Bureau of Economic Research; MIT Press, Cambridge, MA, USA, 1986.

11. Rao Govinda, M. Govinda Rao Warns of High Fiscal Deficit. The Financial Express, 8 July 2009.

12. Rangarajan, C. Rates May Harden by Fiscal End. Business Standard, 18 September 2009. 
13. Johansen, S.; Juselius, K. Maximum likelihood estimation and inference on co-integration-with applications to the demand for money. Oxford Bull. Econ. Stat. 1990, 52, 169-210.

14. Geske, R.; Roll, R. The Fiscal and Monetary Linkages between Stock Returns and Inflation. J. Financ. 1983, 38, 1-33.

15. Gale, W.G.; Orszag, P.R. Budget Deficits, National Savings and Interest Rates. Brook. Panel Econ. Act. 2004, 35, 101-210.

16. Engen, E.M.; Hubbard, R.G. Federal Government Debt and Interest Rates; Working paper, National Bureau of Economic Research; MIT Press, Cambridge, MA, USA, 2004.

17. Laopodis, N.T. Dynamic Interactions among the Stock Market, Federal Funds Rate, Inflation, and Economic Activity. Financ. Rev. 2006, 41, 520-525.

18. Osamwonyi, I.O.; Evbayiro-Osagie, E.I. The relationship between macroeconomic Variables and stock market Index in Nigeria. J. Econ. 2012, 3, 55-63.

19. Asaolu, T.O.; Ogunmuyiwa, M.S. An Econometric Analysis of the Impact of Macroeconomic Variables on Stock Market Movements in Nigeria. Asian J. Bus. Manag. 2011, 3, 72-78.

20. Osahon, I.S.; Oriakhi, D.E. Fiscal Deficits and Stock Prices in Nigeria: An Empirical Evidence. Ekon. Misao Praksa Dbk 2013, 22, 259-274.

21. Saleem, F.; Yasir, M; Ahmed, K.; Sebrish, S. Budget deficits and stock prices: Evidence from Pakistan and India. Interdiscip. J. Contemp. Res. Bus. 2012, 4, 176-185.

22. Van Aarle, B.; Garretsen, H.; Gobbin, N. Monetary and Fiscal Policy Transmission in Euro-Area: Evidence from a Structural VAR Analysis. J. Econ. Bus. 2003, 55, 609-638.

23. Udegbunam, R.I.; Oaikhenan, H.E. Interest Rate Risk of Stock Prices in Nigeria: Empirical Test of the Duration and Convexity Model. J. Emerg. Mark. Financ. 2012, 11,93-113.

24. Ardagna, S. Financial Markets' Behavior around Episodes of Large Changes in the Fiscal Stance. Eur. Econ. Rev. 2009, 53, 37-55.

25. Darrat, A.F. Stock Returns, Money and Fiscal Deficits. J. Financ. Qual. Anal. 1990, 25, 387-398.

26. Fama, E.F.; Schwert,W.G. Asset returns and inflation. J. Financ. Econ. 1977, 5, 115-146.

27. Schwert, G.W. The adjustment of stock prices to information about inflation. J. Financ. 1981, 36, $15-29$.

28. Fama, E.F. Stock returns, real activity, inflation and money. Am. Econ. Rev. 1981, 71, 545-565.

29. Quayes, S.; Jamal, A. Does inflation affect stock prices? Appl. Econ. Lett. 2008, 15, 767-769.

30. Gallagher, L.; Taylor, M. The stock return-Inflation puzzle revisited. Econ. Lett. 2002, 75, 147-156.

31. Gallagher, L.; Taylor, M. Permanent and temporary components of stock prices: Evidence from assessing macroeconomic shocks. South. Econ. J. 2002, 69, 345-362.

32. Rapach, D. The long-run relationship between inflation and real stock prices. J. Macroecon. 2002, 24, 331-351.

33. Feldstein, M. Inflation and the stock market. Am. Econ. Rev. 1980, 70, 839-847.

34. Al-Khazali, O.; Pyun, C. Stock prices and inflation: New evidence from the Pacific-Basin countries. Rev. Quant. Financ. Account. 2004, 22, 123-140.

35. Spyrou, S. Are stocks a good hedge against inflation? Evidence from emerging Markets. Appl. Econ. 2004, 369, 41-48.

36. Pearce, D.K.; Roley, V.V. Stock Prices and Economic News. J. Bus. 1985, 58, $49-67$. 
37. Hardouvelis, G.A. The predictive power of the term structure during recent monetary regimes. J. Financ. 1988, 43, 339-356.

38. Maysami, R.C.; Koh, T.S. A Vector Error Correction of the Singapore Stock Market. Int. Rev. Econ. Financ. 2000, 9, 79-96.

39. Bailey, K. Macroeconomic Fluctuations, Economic Policy and the Jamaican Stock Market; Working Paper; Bank of Jamaica: Kingston, Jamaica, 2000.

40. Maskay, B.; Chapman, M. Analyzing the Relationship between Change in Money Supply and Stock Market Prices; Honors Projects Paper 35; Illinois Wesleyan University Economics Department, Bloomington, IL, USA, 2007.

41. Bernanke, B.S.; Kuttner, K.N. What Explains the Stock Market's Reaction to Federal Reserve Policy. J. Financ. 2005, 60, 1221-1257.

42. Alatiqi, S.; Fazel, S. Can money supply predict stock prices? J.Econ.Educ. 2008, 8, 54-59.

43. Gan, C.; Lee, M.; Yong, H.H.A.; Zhang, J. Macroeconomic Variables and Stock Market Interactions: New Zealand Evidence. Invest. Manag. Financ. Innov. 2006, 3, 89-101.

44. Hsing, Y. Impacts of Fiscal Policy, Monetary Policy, and Exchange Rate Policy on Real GDP in Brazil: A VAR Model. Available Online: http://econpapers.repec.org/article/bejissued/ v_3a6_3ay_3a2004_3ai_3a1_3ahsing.htm (accessed on 22 August 2015).

45. Arango, L.E.; Gonzalez, A.; Posada, C.E. Returns and interest rate: A nonlinear relationship in the Bogotá stock market. Appl. Financ. Econ. 2002, 12, 835-842.

46. Uddin, M.G.S.; Alam, M.M. The Impacts of Interest Rate on Stock Market: Empirical Evidence from Dhaka Stock Exchange. South Asian J. Manag. Sci. 2007, 1, 123-132.

47. Alam, M.M.; Uddin, M. Relationship between interest rate and stock price: Empirical evidence from developed and developing countries. Int. J. Bus. Manag. 2009, 4, 43-51.

48. Gregorio, R.L. The relationship between Philippine interest rates and stock price movements. Philipp. Rev. Econ. Bus. 1994, 31, 33-51.

49. Naik, P.K.; Padhi, P. The Impact of Macroeconomic Fundamentals on Stock Prices Revisited: Evidence from Indian Data. Eurasian J. Bus. Econ. 2012, 5, 25-44.

50. Singh, D. Causal relationship between macroeconomic variables and stock market-A case study of India. Pak. J. Soc. Sci. 2010, 30, 263-274.

51. Tripathi, V.; Seth, R. Stock Market Performance and Macroeconomic Factors: The Study of Indian Equity Market. Global Bus. Rev. 2014, 15, 291-316.

52. Homa, K.E.; Jaffee, D.M. The Supply of Money and Common Stock Prices. J. Financ. 1971, 26, 1056-1066.

53. Kessel, R.A. Inflation caused wealth redistribution: A test of hypothesis. Am. Econ. Rev. 1956, 46, 128-141.

54. Ioannidis, D.; Katrakilidis, K.; Lake, A.E. Inflation, Uncertainty and Stock Market Returns Evidence Using Greek Data; Department of Economics, University of Macedonia, Thessaloniki, Greece, 2004.

55. Pesaran, M.H.; Shin, Y.; Smith, R.J. Bound Testing Approaches to the Analysis of level Relationships. J. Appl. Econom. 2001, 16, 289-326.

56. Engle, R.F.; Granger, C.W.J. Co-integration and error correction: Representation, estimation, and testing. Econometrica 1987, 55, 251-276. 
57. Juselius, K. Testing structural hypotheses in a multivariate cointegration analysis of the PPP and the UIP for UK. J. Econom. 1992, 53, 211-244.

58. Kim, T.-K.; Leybourne, S.; Newbold, P. Behaviour of Dickey-Fuller Unit-Root Tests Under Trend Misspecification. J. Time Ser. Anal. 2004, 25, 755-764.

59. Perron, P. The Great Crash, the Oil Price Shock, and the Unit Root Hypothesis. Econometrica 1989, 57, 1361-1401.

60. Perron, P. Further Evidence on Breaking Trend Functions in Macroeconomic Variables. J. Econom. 1997, 80, 355-385.

61. Granger, C.W.J. Investigating Causal Relations by Econometric Models and Cross-spectral Methods. Econometrica 1969, 37, 424-438.

62. Ng, S.; Perron, P. Lag Length Selection and the Construction of Unit Root Test withGood Size and Power. Econometrica 2001, 69, 1519-1554.

63. Narayan, P.K.; Narayan, S. Savings behaviour in Fiji: An empirical assessment using the ARDL approach to cointegration. Int. J. Soc. Econ. 2006, 33, 468-480.

64. Brook, C. Introductory Econometrics for Finance; Cambridge University Press: Cambridge, UK, 2008.

65. Kuszczak, J.; Murray, J.D. A VAR Analysis of Economic Interdependence: Canada, the US and the Rest of the World; 1987. Available online: https://research.stlouisfed.org/publications/ review/86/conf/murrary.pdf (accessed on 22 August 2015)

66. Sims, C. Macroeconomics and Reality. Econometrica 1980, 48, 1-48.

67. Adrangi, B.; Allender, M. Budget Deficit and Stock Prices: International Evidence. J. Econ. Financ. 1998, 22, 57-66.

(C) 2015 by the authors; licensee MDPI, Basel, Switzerland. This article is an open access article distributed under the terms and conditions of the Creative Commons Attribution license (http://creativecommons.org/licenses/by/4.0/). 